\title{
Advantages and contributions in the balanced scorecard implementation
}

\author{
Patrícia Quesado1 (D), Beatriz Aibar Guzmán² (D), Lúcia Lima RodriguesiD \\ ${ }^{1}$ Instituto Politécnico do Cávado e do Ave (Portugal) \\ ${ }^{2}$ Universidad de Santiago de Compostela (Spain) \\ ${ }^{3}$ Universidade do Minho (Portugal) \\ pquesado@ipca.pt,beatria.aibar@usc.es,_rodrigues@eeg.uminho.pt
}

Received July, 2017

Accepted October, 2017

\section{Abstract}

Purpose: In this paper we aim to identify and analyse a set of advantages and contributions derived from the Balanced Scorecard (BSC) implementation.

Design/methodology: In order to answer the research question, we have carried out a qualitative research based on the exclusively bibliographical review of theoretical / conceptual and empirical works previously done on the subject (systematic review of the literature).

Findings: The results allow us to conclude that the BSC is more than a simple performance evaluation system, to become a true strategic management tool able to clarify and translate the mission and organizational strategy, making possible the communication process, the strategic alignment and the organizational learning.

Originality/value: The study presents a contribution to the current state of knowledge, since the identification of the advantages and contributions in the BSC introduction and implementation can facilitate its adoption and development in the organizations that intend to implement this tool. In addition, a theoretical basis is provided for subsequent research, evidencing the breadth of research on the topic studied.

Keywords: Balanced scorecard, Management accounting and control, Advantages

Jel Codes: M40, M49

\section{Introduction}

Many leading companies unquestionably began to adopt the Balanced Scorecard (BSC) when they verified that it enabled them to improve their performance by linking their subunits and members in a concerted effort to increase the organization's goals and global objectives. In fact, during this literature review, we found numerous work that refers to a set of advantages, strengths and contributions of the BSC for organizations.

The BSC is an adequate tool to select a balanced set of indicators and objectives that reflect the strategic vision of the organization, helping organizations to meet their stakeholders' expectations, to articulate and communicate strategic objectives and to evaluate their implementation, i.e., it transforms the mission and strategic objectives into actions, allows members to communicate with each other and perceive their contribution 
in the scope of the organizational mission, enables improvements in the quality of the services provided and continuous feedback and learning. Thus, it represents a balance between external measures related to shareholders and customers and internal measures related to critical processes, such as innovation, learning and growth (Kaplan \& Norton, 2000). However, some studies have highlighted the fact that despite the large amount of advantages associated with the implementation of the BSC, its use has not been generalized in many organizations, mainly motivated by a set of barriers that can prevent or limit its chances of success.

In this sense, it seems worth asking: What are the main advantages and contributions in the BSC implementation? (research question). Thus, the main objective of this paper is to identify and analyse a set of advantages and contributions associated with introducing and implementing the BSC in organizations, in the sense of facilitating its adoption and development in organizations that aim to implement this tool, providing a theoretical basis for subsequent research and showing the scope of research regarding this topic.

The literature review was the methodology used to analyse previous published papers regarding this topic. Different authors have highlighted the need to develop studies regarding the introduction and implementation of the BSC since it is an area that has not yet been explored much (Tayler, 2010; Modell, 2012; Lueg \& Silva, 2013; Hoque, 2014; Madsen \& Stenheim, 2015; Lueg \& Julner, 2014; Lueg, 2015). In addition, as Short (2009) points out, bibliographic review studies are important when dealing with management models introduced many years ago. It is precisely the case of the BSC, which was developed at the beginning of the 90's by Kaplan and Norton (1992, 1993, 1996), as a management tool capable of overcoming the limitations of traditional information and management control systems, in particular, the absence of a strategic approach.

We understand that the identification of the advantages or factors that facilitate the introduction and implementation of the BSC can improve its users' satisfaction and interest and consequently, reduce the failure rate, disinvestment or its gradual withdrawal by organizations.

In accordance with the goal set, we have structured the work in the following way: initially, some theoretical aspects related to the benefits/advantages derived from the implementation of the BSC are extensively reflected. Next, the main contributions resulting from the adoption of the BSC for organizations are presented. Based on this, a review of some empirical studies carried out in organizations of different nature (private and public), size [large companies and small and medium-sized enterprises (SMEs)] and sector of activity (banking, health and hotel) and its main conclusions.

\section{Methodological procedures}

In order to respond to the research question, we carried out qualitative research based on an exclusively bibliographic review of theoretical/conceptual and empirical papers, previously carried out on the subject (systematic review). According to Lueg (2015), the methodology of the systematic review of the literature allows a review of the evidence on a clearly formulated question, using systematic and explicit methods to identify, select and evaluate critically relevant primary research and extract and analyse data from the studies included in the review. According to Sampaio and Marcini (2007), a systematic review allows the integration of information from a set of studies carried out separately and identifies topics that require future research. It is an investigation of bibliography developed by taking into account studies already carried out, classified as descriptive, since it aims to describe the characteristics of a particular population or phenomenon (Gil, 2010). Agarwal (2012) and Short (2009) point out that literature review articles provide relevant information and different perspectives for a set of different users, as they collect, organise, evaluate and integrate scientific evidence.

Bibliographic research was carried out from 2002 until the end of 2016, especially in the Online Knowledge Library (b-on), which allows unlimited and permanent access to research and higher education institutions, to full texts from several scientific newspapers and ebooks online of some of the most important content providers. We have also consulted papers presented in national and international congresses/conferences, where we have participated, as well as books and theses published on the subject, to ensure broad coverage of literature beyond a limited selection of journals. We also checked the references of the articles that we considered the most 
relevant to identify other potentially relevant studies on the implementation of the BSC that had been published in other sources.

We look for the expressions "Balanced Scorecard and Advantages" and "Balanced Scorecard and Critical Success Factors", selecting the articles considered most relevant in terms of title, summary and keywords.

It is important to point out that our aim is not to develop a new model or a new theory, but to resort to current literature on this subject, in order to summarise, explore, analyse and help in the understanding of these issues, providing a critical and exhaustive view on them in order to raise inquiries and new theoretical perspectives.

\section{Literature review}

\subsection{BSC benefits}

Several papers refer to a set of benefits/advantages and strengths of the BSC for organizations. In its creators 'opinion, the most innovative aspect of the BSC is its capacity to generate strategic learning, providing a global vision of organizational performance and favouring the understanding of organizational objectives, minimizing the overload of information by limiting the number of measures used through four perspectives (financial, customer, internal processes and learning and growth). In this sense, it forces managers to focus exclusively on the most critical set of measures for the performance of the organization, acting as a control system by exception (this aspect was also mentioned in the studies by Kanji and Sá (2001) and Epstein and Manzoni (1997, 1998)). Thus, the BSC is configured as the ideal tool for change in management control, capable of providing a framework, structure and language to communicate the mission and strategy, using measurements to inform employees about the causes of present and future success (Kaplan \& Norton, 1992, 1993, 1996a, 1996b, 2000, 2001, 2004, 2007a, 2007b).

For these authors, the BSC increases the ability of organizations to implement the strategy and increase their performance by overcoming the limitations of purely financial indicator systems, clearly portraying value creation processes and the critical roles of intangible assets, i.e., it describes numerous indirect links necessary to connect an organization's improvements in intangible assets with the tangible results on customers and financial aspects of the strategy.

According to Kaplan and Norton (1996b), the use of the BSC in the development of strategic initiatives helps managers to focus on issues that promote growth, and not only on those that reduce costs and increase efficiency. Thus, the BSC provides a more complete and complex analysis of organizational performance, configuring a system of indicators (leading and lagging) that enables its integrated holistic vision, allowing to focus the efforts of organizations, defining and communicating priorities to managers, employees, investors and customers. Moreover, the main advantage of the BSC compared to traditional scorecards lies precisely in the internal consistency achieved between strategic objectives and indicators.

For Olve, Roy and Wetter (2002), the BSC has the advantage of being a compact model, where its correct implementation allows to:

- Provide management with control of strategic dimensions;

- Communicate the individual contribution of each employee clearly;

- Discuss the benefits that can result from investments in the development of competences, the increase in relationships with clients and in Information Technology (IT);

- Enable the creation of opportunities for systematic learning (by focusing on critical success factors for the organization);

- Raise awareness among employees that not all decisions will have immediate results in increasing benefits or reducing costs;

- Show what the company can do to complete the information disclosed in financial reports. 
In short, the BSC can be the "cornerstone" of an organization's management system by helping to (Lueg, 2015; Zizlavsky, 2014; Hoque, 2014; Tapinos, Dyson \& Meadows, 2011; Braam \& Nijssen, 2011; Sundin, Granlund \& Brown, 2010; Chavan, 2009; Dhingra, 2006; Speckbacher, Bischof \& Pfeiffer, 2003; Niven, 2003; Kaplan \& Norton, 2000, 2001; Otley, 1999; Chow, Haddad \& Williamson, 1997):

- Clarify and update the organization's strategy and vision (obtain consensus on the strategy and vision to follow and a greater degree of uniformity between the different opinions);

- Translate the mission and strategy of an organization into concrete actions and a set of indicators that inform of the achievement of the objectives and the causes that motivated the results obtained;

- Facilitate internal communication of the strategy, vision and strategic objectives (communicate clearly the way to follow and how to improve performance throughout the entire organization, and link strategic objectives and indicators through cause-effect relationships);

- Improve the use of available resources;

- Encourage the achievement of objectives without causing imbalances between potential success factors;

- Align personal objectives and those of the departments and units with the business strategy (favouring the achievement of synergies and development of the spirit of cooperation);

- Link strategic objectives to long, medium and short-term goals and to the respective annual budgets (assigning the necessary resources to achieve the objectives);

- Promote improvement programmes, such as process re-engineering and total quality management (without the BSC, these programmes could focus on processes that are not critical to strategic success, not helping to achieve the expected financial result);

- Promote the visualization process and monitor the results achieved (the BSC is not a static model);

- Allow the teams and all the members of the organization to concentrate on its strategic priorities;

- Obtain feedback that encourages continuous learning and improves strategic formulation, identifying new initiatives and favouring the review of strategies on a regular and systematic basis;

- Identify and align the initiatives that lead to strategic objectives by creating a coherent structure of strategies, objectives, goals and indicators that enable to build a dynamic strategic plan;

- Build a sense of confidence in the performance compensation system (quantifying and clarifying the evaluation criteria).

Table 1 summarizes the strengths of the BSC, as well as some benefits that may result from its implementation in organizations. 


\begin{tabular}{|l|l|}
\hline \multicolumn{1}{|c|}{ Benefits } & \multicolumn{1}{|c|}{ Strengths } \\
\hline $\begin{array}{l}\text { Establishing a business model and translating it into } \\
\text { indicators facilitates consensus for the entire company, } \\
\text { not only of the management, but also on how to achieve } \\
\text { it. }\end{array}$ & $\begin{array}{l}\text { Organizational consensus in relation to the strategy: it facilitates } \\
\text { the consensus of the entire company by clarifying and } \\
\text { translating the mission and strategy into manageable terms for } \\
\text { the entire organization. }\end{array}$ \\
\hline $\begin{array}{l}\text { It clarifies how day-to-day actions affect not only the } \\
\text { short-term, but also the long-term (easily applicable to } \\
\text { the control of daily work). }\end{array}$ & $\begin{array}{l}\text { Translation of the strategy in operational terms: it } \\
\text { communicates the strategic objectives in practical terms and } \\
\text { enables to link them to each other through cause-effect } \\
\text { relationships. }\end{array}$ \\
\hline $\begin{array}{l}\text { Once the BSC is in action, it can be used to } \\
\text { communicate the company's plans, direct efforts in one } \\
\text { direction, avoiding dispersion. }\end{array}$ & $\begin{array}{l}\text { Budget-strategy relationship: it allows the budget to be linked to } \\
\text { the strategy, through the allocation of adequate resources to } \\
\text { achieve the objectives. }\end{array}$ \\
\hline $\begin{array}{l}\text { It can also be used as a tool to learn about the business. } \\
\text { The comparison between the plans and the current } \\
\text { results actually helps the management team to reassess } \\
\text { and adjust both the strategy and action plans. }\end{array}$ & $\begin{array}{l}\text { Learning tool, by comparing plans and results with the objective } \\
\text { of evaluating and adjusting strategic objectives, indicators and } \\
\text { action plans. }\end{array}$ \\
\hline $\begin{array}{l}\text { Support for objectives and organizational strategies (the } \\
\text { measures are aimed at the strategy). }\end{array}$ & \begin{tabular}{l} 
Possibility of implementation in any type of entity. \\
\hline $\begin{array}{l}\text { Structure and procedures based on systemic conception } \\
\text { (complements financial measures with non-financial } \\
\text { ones): structured model that defines measures for all } \\
\text { organizational levels (operational flexibility). }\end{array}$
\end{tabular} $\begin{array}{l}\text { Simple model, conforming to the principles or foundations of } \\
\text { performance measurement (it provides a broad view of how to } \\
\text { implement a performance measurement system). }\end{array}$ \\
\hline
\end{tabular}

Table 1. Benefits and Strengths of the BSC (Oliva \& Borba, 2004; Santos \& Fidalgo, 2004, adapted)

\subsection{Classification of the advantages}

Based on the above, we can classify the advantages of the BSC into two main groups: advantages at the organizational strategy level (definition, communication and implementation) and advantages at the strategic alignment level.

\subsubsection{Advantages at the organizational strategy level}

Research carried out by different authors revealed that the BSC has been used successfully to manage the longterm strategy. For Kaplan and Norton (2001), the BSC emphasizes the importance of the strategy as a framework for future action on which to focus all the resources of the organization. This means that the entire organization contributes to the achievement of strategic objectives through the deployment of indicators, goals, initiatives and personal alignment, highlighting through the perspectives, that not only financial measurements, which reflect past results are important, but the engine of future success must also be measured, i.e. customers, internal processes, resources, growth. Thus, it will allow for the visualization of the strategy deployment through the design of strategy maps.

In this regard, it is also important to point out that the cascade process of the BSC "captures" the synergies and commitment of the various employees, focusing decision-making on obtaining the business strategy. In this line, Chow et al. (1997) consider that the main advantage of the BSC has to do with the visualization of the strategy, the structure and the organizational vision in the core of the organization, which involves an integrated combination of traditional and non-traditional performance measures, the management being focused on the entire business process and ensuring that current performance is in line with the long-term strategy and customer values. The authors consider that the novelty of the BSC is in the simple and integrated design of its elements, focusing specifically on the needs of the organization. Thus, the BSC facilitates the definition of the strategy in operational terms and allows a simple description and its effective communication, making possible systematic dialogue on strategic issues between the organization members, the strategy link to the activities of the people and their departments, and continuous evaluation of strategy achievement (Michalska, 2005; Ritter, 2003).

For Headley (1998, pp. 36) "developing and launching a BSC is a golden opportunity to discuss, clarify and document the company's strategy (...), provoking a debate about what the company's objectives are, and how 
they should be achieved". Thus, it plays an important role at the information level provided to managers, in particular, knowledge about the implementation level and specification of the strategy and what the causes of possible deviations are. In the opinion of Santos and Fidalgo (2003, pp. 242), "the BSC has evolved to give more importance to the ability to execute, implement and follow a strategy than to the quality of the strategy itself. This is a new and contrasted phenomenon, and the application of the strategy is even considered as the most important factor in the assessment of a company and its management".

According to Atkinson and Epstein (2000, pp. 24), the BSC "has changed the way managers think about organizational management. They began to develop and articulate the strategy more carefully, to think of the organization as an integrated and coordinated set of activities, linking the strategy to performance measures and connecting the strategy and measures to compensation". In this sense, according to Morisawa and Kurosaki (2003), introducing the BSC increases the capacity to establish strategies and improve their quality (through the reduction of strategic objectives and the prevention of omissions), enabling their dissemination at lower organizational levels (promoting an active exchange of opinions about the strategies between participants). In this way, the strategies will be more successful than before, once the situation of achieving strategic objectives is clarified and the results are reflected in performance evaluations. In the words of Fernández (2002, pp. 13), "organizations seek in the BSC to solve certain problems related to the strategy and its implementation that continue to exist in many companies. The BSC aims to be not only a strategic clarification instrument, but also an information instrument in the entire organization and even outside of it".

In contrast to the above, the BSC helps to simplify the complexity of management and decision processes by prioritizing objectives and initiatives and promoting internal learning, especially to integrate and relate a set of elements coherently that connect the strategy and organizational actions (Oteo, Pérez \& Silva, 2002). In this context, Malina and Selto (2001) emphasize that the BSC presents significant opportunities to develop, communicate and implement the strategy, especially through strategic maps, and visualize the cause-effect relationships between the different strategic objectives. Thus, a good BSC is also a vehicle for internal communication, and should not be confidential information of the management, but should be shared with all the employees, whose work will be enriched by their greater knowledge of the company's strategy, and to what extent their work affects it.

\subsubsection{Advantages at the strategic alignment level}

Theoretically, the BSC is presented as an excellent initiative that makes it possible to link the mission and strategy to performance measures and strategically aligned initiatives. In fact, the BSC can be a viable tool for managers. Firstly, it enables a tangible link of the mission and the organizational strategy, which can increase the workforce morale, which is considered an active element in the whole process. Secondly, the implementation of the BSC involves all levels of the organization in reaching a common goal, developing a spirit of cooperation. Thirdly, the BSC helps to improve communication and visibility between senior executives and lower-level employees. In this sense, for Niven (2003), Brewer (2003, 2002), Mooraj, Oyon and Hostettler (1999) and Butler, Letza and Nealy (1997), the BSC allows organizations to build a high performance culture, to the extent that it promotes the alignment of key indicators to the strategic objectives of the company in each and every organizational level.

According to Hendricks, Hora, Menor and Wiedman (2012) and Hendricks, Menor and Wiedman (2004), strategic alignment improves the understanding of organizational capacities, the objectives of working groups and the link between decisions, actions, and strategic objectives, enabling the redefinition of relationships with customers and the reengineering of fundamental business processes. At the same time, Pinto (2007) highlights that the BSC presents a set of innovations in relation to other strategic management models, in particular, the way in which the indicators are organized and aligned, the ease with which it can be disseminated in the organization, making it possible to know about the strategic frameworks without compromising the confidentiality to which some of the aspects may be subject to, and the unfolding of the indicators and objectives by the organization and their quantification. Thus, for Hepworth (1998), the main advantage of the BSC is related to the joint design of all the key business areas and the identification of the sequences of actions that lead to success. On the other hand, Alvarez (1998) highlights the extension of the financial measures used in 
conventional accounting with quantitative and qualitative information; the balance and adequate weighting between financial and non-financial measures; and the special attention given to customer satisfaction and loyalty, in the motivation of employees and IT as essential for improving results and competitiveness and the performance of efficient production processes. In this line, the BSC facilitate stop-down communication of the objectives and their alignment to the strategy.

\subsection{Contributions of the BSC}

For Hoque (2014), Lueg (2015), Braam and Nijssen (2011), Sundin et al. (2010), Chavan (2009), Lawson, Stratton and Hatch (2006), Santos and Fidalgo (2005, 2004), Morisawa and Kurosaki (2003) and Frigo and Krumwiede (1999a, 1999b), the contributions made by the use of the BSC are in general the following:

- It converts the strategy into action and allows to obtain a shared vision of it. Thus, all the organization members will be able to know about the link of strategic actions with the vision and mission, and the impact of its contribution;

- It provides a systematized vision of operational performance, constituting a validation and updating process of the strategy;

- It is an information and control instrument that communicates the mission and strategic objectives to the whole organization, which raises coherence in all actions, since it allows to align the objectives of each employee with those of the organization;

- It allows to understand the performance of sections where it is difficult to examine them in quantitative data terms (establish smooth communication with other departments, using a common language and thinking);

- It is a coordination, motivation and training instrument, since it involves learning good actions developed and errors, i.e., it allows to develop a learning culture;

- It allows the integration of internal and external performance measures;

- It allows to adopt strategic decisions more quickly thanks to the availability of better data;

- It requires the coordination of planning tasks with the strategy, focusing the organization towards the strategic objectives;

- It increases productivity;

- It makes increasing income and reducing costs possible, and consequently, improves financial performance;

- The identification of the key success factors favours reengineering and continuous improvement;

- It allows for attribution of responsibility;

- It contributes to a permanent review and redefinition of the strategy, since reality changes.

The main contribution of the BSC, in the opinion of Muñiz and Monfort (2005) and Muñiz (2004), is that it focuses on improving business results and the best possible use of available resources. Thus, it represents the essence of what the most important for the company is and for each level of responsibility, it communicates the priorities of the strategy, it includes information on the environment, it makes the strategy operational, with indicators that measure the implementation level, it balances the areas, it increases participation and motivation of managers and employees, and makes it possible to foresee the future. These authors present a set of key elements provided by the BSC (Table 2). 


\section{Contributions}

Comprehensive vision of the company's business system, overcoming It serves as a basis for prediction (using the traditional methods of performance measurement (inclusion of indicators to predict the effects in the future).

tangible and intangible assets) and focusing on critical activities for the creation of value.

Communication, execution and implementation of the strategy It evaluates and adjusts both the strategy and the (translating the objectives set out in the strategy into concrete actions action plans by analysing deviations.

and results, allowing the company's management to focus its attention on what it considers most important to achieve the foreseen strategic objectives).It is a highly valued instrument, as proof of a new style of effective and modern management (when a change of leadership occurs).

Balance and alignment of the objectives between the different It allows for improvements in quality and managers, departments, divisions, etc. productivity with immediate effects.

It focuses attention on increasing revenue and not only on cutting costs It specifies the business model, facilitating the and increasing productivity to achieve greater growth. achievement of consensus in all the company on what the strategy is and how it can be reached.

In times of change, it provides the bases or indicators for the future or It assigns people responsible for certain strategic to implement new strategies (mergers or important strategic changes, it objectives.

highlights a change in leadership style, it summarizes the information in synthetic tables to focus on the most vital aspects of the company, and facilitates the path that must be followed in times of business crisis).

It is a highly valued instrument as proof of a new style of effective and It reduces traditional planning and budgeting modern management (when a change of leadership occurs). processes.

It includes information related to the company's environment (market, It motivates and rewards employees (support for competition, suppliers, etc.).

variable remuneration).

Table 2. BSC Contributions (Muñiz \& Monfort, 2005; Muñiz, 2004)

On the other hand, De Geuser, Mooraj and Oyon (2009), Michalska (2005), Ritter (2003), Kanji and Sá (2001) and Epstein and Manzoni $(1997,1998)$ consider that the main contributions of the BSC model are the following:

- Putting together in a report "apparently divergent elements" of the organizations' competitive agenda, i.e., summarizing a set of performance indicators, related to the four basic perspectives in a single simple and concise document, facilitating their analysis and making explicit relationships between the measures;

- Systematic development and translation of the vision and the strategy of the organization into tangible objectives and measurable performance measures, through the use of indicators to communicate the strategy and to measure the success of its implementation;

- Specification of the critical success factors and their interrelation;

- Holistic approach to the evaluation of organizational performance (providing through the perspectives, a more balanced and global vision of the organization, highlighting the benefits of certain measures to the detriment of others);

- Promoting holding meetings to discuss data, assumptions and action plans, involving regular attention of the various participants in the organization and contributing to learning at the level of the activities and implementation processes;

- Flexibility and adaptability to different types of organizations;

- Strong attention to customers and the market;

- A clearer and shared vision of what is to be achieved and of the means to be used to make this possible;

- Cause and effect analysis, identifying all the activities that are performed to reach the established objectives and to which it is convenient to assign the company resources.

The fact that the BSC highlights the most decisive and important processes to achieve good performance with respect to clients and shareholders, is highlighted by Carvalho and Azevedo (2001) as one of the innovations and 
advantages of the BSC. Regarding clients, Dhingra (2006) claims that the BSC allows executives to listen to clients in a strategic routine and, ultimately, to acquire, develop and retain the most valuable relationships with clients. By placing the client at the core of the strategy, organizations can find success indicators and adjust their internal processes accordingly. Thus, the BSC provides a powerful tool for an organization to quickly implement a radical strategic change, i.e., the BSC is not only a set of measures and a performance model of the organization, but also allows to identify the conflicting measures and prioritize them. In addition, the BSC helps in particular with new markets, products and segments by measuring the financial results in each of these areas. The BSC also motivates the organization to innovate with creativity and launch products more quickly by establishing appropriate internal processes, objectives and measures.

In short, the BSC improves the quality of control systems in different ways. Firstly, through the selection of appropriate measures, it enables the incorporation of many of the management principles into a single document. Secondly, it expands beyond the historical analysis of financial data. Thirdly, it ensures that top management permeates strategic objectives throughout the company. At the same time, however, middle managers can adapt the BSC to their respective operating units by adding goals and indicators as required. Thus, it establishes a flexible and formal mechanism between the company's strategy and operational control. On the other hand, with a BSC, managers can easily direct their attention to the variables that influence the success of the company at any level of organization. In the fourth place, information also facilitates comparisons of performance between companies and between the different organizational units (Rickards, 2003)

\section{Review of empirical studies}

For Ballvé (2006), the experiences of BSC implementation have turned it into a basic, formal, integral and highvalue management system, which ranges from the planning system to incentives, and which involves all measurements at different organizational levels. Thus, the value of the BSC is not having a set of techniques superior to other management and performance measurement systems, but to being an open tool that allows people to interpret, negotiate, modify and combine with existing routines so that they adapt to the local conditions. In fact, in an environment of uncertainty and complexity, it is important to highlight the capacity of the BSC to adapt to different sectors and to the nature of disparate organizations.

In view of the above, in recent years numerous studies have been developed in different countries on the applicability and positive aspects resulting from the application of the BSC in organizations of different nature, size and sector of activity.

In Portugal, Quesado (2005) conducted an empirical study in large companies, concluding that $84.6 \%$ of the companies indicated an improvement in the alignment between strategic objectives and actions as a positive aspect, followed by benefits related to the clarification and communication of the strategy, as well as with the development of a consistent system of objectives, both in $76.9 \%$ of cases. The fact that the BSC has eased the implementation of the strategy and its additional development (69.2\%) and the improvement in the measurement of organizational performance $(65.4 \%)$ is worth making special mention to. Some years later, Quesado, Guzmán and Rodrigues (2012a, 2012b) developed an empirical study, based on the approaches of the Theories of Contingencies and Institutional, in which one of the objectives was to identify the benefits and changes derived from the implementation of the BSC in Portuguese public organizations (municipalities, hospitals and municipal/inter-municipal companies) and private organizations (large companies and small and medium-sized enterprises). Regarding the cost/benefit analysis of implementation, most of the analysed organizations consider that the benefits exceeded the costs and some even think that they well exceeded the costs.

Regarding the benefits derived from the implementation of the BSC, as shown in Table 3, 79.5\% of private organizations highlighted an improvement in the alignment between strategic objectives and actions as a positive aspect. The following benefits indicated are related to the development of a consistent system of objectives and indicators $(74.4 \%)$ and the clarification and communication of the strategy $(69.2 \%)$. In the case of public organizations, $91.7 \%$ highlighted the fact of facilitating the implementation of the strategy and its additional 
development as positive aspects, followed by an improvement in organizational performance (83.3\%) and clarification and communication of the strategy $(75 \%)$.

\begin{tabular}{|c|c|c|c|c|}
\hline \multirow[t]{2}{*}{ Benefits } & \multicolumn{2}{|c|}{$\begin{array}{c}\text { Private } \\
\text { organizations } \\
(n=39)\end{array}$} & \multicolumn{2}{|c|}{$\begin{array}{c}\text { Public } \\
\text { organizations } \\
(n=12)\end{array}$} \\
\hline & $\mathbf{N}$ & $\%$ & $\mathbf{N}$ & $\%$ \\
\hline It facilitated the implementation of the strategy and its additional development & 20 & 51.3 & 11 & 91.7 \\
\hline Clarification and communication of the strategy & 27 & 69.2 & 9 & 75 \\
\hline Development of a consistent system of objectives and indicators & 29 & 74.4 & 8 & 66.7 \\
\hline Improvement in organizational performance & 21 & 53.8 & 10 & 83.3 \\
\hline Increase in economic-financial results & 7 & 17.9 & 5 & 41.7 \\
\hline Improvement in the alignment between strategic objectives and actions & 31 & 79.5 & 7 & 58.3 \\
\hline It provided support for the implementation of changes & 12 & 30.8 & 6 & 50 \\
\hline Achievement of synergies between units, teams, areas and sectors & 7 & 17.9 & 4 & 33.3 \\
\hline Improvement in strategic learning (control and feedback) & 19 & 48.7 & 6 & 50 \\
\hline Improvement in the attention provided to customers/citizens/users & 8 & 20.5 & 6 & 50 \\
\hline Reduction of emphasis on short-term financial measures & 5 & 12.8 & 1 & 8.3 \\
\hline Emphasis/integration of non-financial performance indicators & 20 & 51.3 & 5 & 41.7 \\
\hline Investment in intangible assets increased & 1 & 2.6 & 1 & 8.3 \\
\hline Redefinition of the strategic planning process & 11 & 28.2 & 5 & 41.7 \\
\hline More efficient cost control & 14 & 35.9 & 6 & 50 \\
\hline Improvement of the quality of the products and/or services provided & 9 & 23.1 & 6 & 50 \\
\hline It facilitated the comparison of performance between different organizations & 13 & 33.3 & 2 & 16.7 \\
\hline Improvement in decision-making with reduction of internal conflicts & 6 & 15.4 & 2 & 16.7 \\
\hline
\end{tabular}

Table 3. Benefits obtained from the implementation of the BSC in Portuguese public and private organizations (Quesado et al., 2012a, 2012b, adapted)

In Portugal, Xavier (2012) also studied the applicability of the BSC in a financial institution highlighting that the BSC contributes to the communication and dissemination process of strategic objectives to the different levels of the organization, to the planning process and definition of performance goals, once it affects the definition of initiatives and action plans for the fulfilment of the objectives, as well as for the allocation of resources to the different initiatives.

Even in the banking sector, Albright and Burgess (2013) concluded that the BSC allows to capture measures considered strategically relevant in a balanced way, and which are used to evaluate the individual and business unit performance, being capable of influencing the rewards system of the organization. On the other hand, Öztürk and Coskun (2014) and Tominac (2014) confirmed in their studies that the BSC helps to achieve harmony and the maintenance of key processes of banks. In addition, Atkinson and Epstein (2000) presented several examples of adoption of the BSC in Canada, highlighting the case of the Montreal Bank that has implemented the BSC to support the management of relationships with its stakeholders. As the authors state, the most important role of the BSC is the systematic attempt to measure and communicate the relationship between the activities developed and the results achieved at operational levels, providing a basis for organizational learning. Thus, the management of operations and strategy will create a new management system that will enable top management to align actions, changes and innovations at different organizational levels.

In the health sector, Bisbe and Barrubés (2012) and Kollberg and Elg (2011) observed that the BSC has the potential to contribute to a better implementation of the strategy based on the measurement and monitoring of results, improving internal and external capacities and supporting organizational development. In the same way, for Pereira (2005), the information produced by the BSC favours desirable continuous reassessment of the defined strategy and the processes used in its implementation.

In the hotel sector, Denton and White (2000) concluded that the BSC allowed to improve the management of the corporation and increase revenues and profitability, anticipating negative trends and providing an overview for all hotels in the chain. In turn, Rodrigues and Francisco (2010) have found that the BSC allows to guarantee 
greater strength in all the hotel activity, focusing on a management concerned with the quality of the service and with the human resources.

Regarding large companies, Hoque and James (2000), in a study conducted in 66 Australian industrial companies, concluded that the BSC allows to improve organizational performance. This conclusion is similar to that obtained in the study carried out by De Geuser et al. (2009) through surveys collected in 76 business units. In addition, the authors concluded that the BSC improves the integration of process management and the competencies of the people in the business unit, enabling a better translation of the strategy in operational terms, the conversion of strategies into a continuous process, and greater alignment of different processes, services, competencies and units of an organization. On the other hand, Bedford, Brown, Malmi and Sivabalan (2008) confirmed that the BSC offers greater benefits when it is linked to the incentives and rewards system, it is applied at multiple levels within the organization and the cause-effect logic is included in the measures.

Finally, despite the predominance of studies on the implementation, characteristics and use of the BSC in large companies, in recent years, some works on the application of the BSC in SMEs have been presented. Thus, for example, Tan and Smyrnios (2011) concluded that the adoption of the BSC in Australian SMEs enabled a combination of financial and non-financial measures that provide them with a comprehensive vision of their businesses to guide the development, implementation and communication of the organizational strategy. Bhagwat and Sharma (2007) conducted three case studies in India, concluding that the BSC not only helps organizations in quicker and wider monitoring of their operations, but can also help them to improve their internal and external functions. In turn, Ottoboni (2002, pp. 33-34) confirmed that the BSC "helps maintain the balance between the development of long-range competitive skills and the recognition of investors' attention in financial reports, which in the competitive strategy context, means creating future value through investment in customers, suppliers, employees, processes, technology and innovation".

\section{Final considerations}

In this paper, it has been possible to verify that the BSC uses a set of fully integrated and coordinated financial and non-financial indicators, through causal relationships that are established with the objectives and goals of the organization. Thus, its flexible nature, its adaptability to the activity and particular circumstances of each organization, its synthetic and synoptic character (which provides a quick and global vision of the company) are outstanding qualities of the BSC.

At the beginning, the BSC was considered a more complete system of indicators than those that had been proposed until that moment, going much farther than the conventional scorecards when considering all the key success factors in an organization and involving the active participation of most of the managers. Thus, in addition to being a useful information and control tool, it enables the coordination of people and encourages their motivation. A few years later, the BSC began to show that it was also very useful to align people coherently with the organizational strategy and to help achieve strategic objectives, constituting a powerful tool to ensure that the strategy is implemented correctly (Horváth \& Partners, 2003).

When the BSC is implemented properly, it has several advantages over traditional financial reports, facilitating the process of change (Walker, 1996). Some of these advantages include greater flexibility, the inclusion of more non-financial information, the communication capacity of the main factors that drive performance, and innovation and organizational learning. In addition, the approach recognizes the effects of the organization's measurement system on the behaviour of the management and employees. Thus, the method forces the organization to explicitly recognize the activities that contribute to success and to develop adequate performance measures.

In conclusion, the BSC is an integral part of the identification of the mission, the formulation of the strategy and its implementation. In this way, it plays an important role in the communication of the organizational strategy by all the members and promotes the feedback process. In fact, used adequately, the BSC performs as a rich source of information and knowledge, ensuring that participants are able to communicate regularly with each other. In addition, it allows to link the long-term strategy with short-term actions and create strategic 
awareness among employees. In this context, the approach adopted by the BSC helps managers to focus on the company's strategy to decide what to measure and how, and how to avoid potential conflicts between different objectives and indicators.

We understand that the study contributes to the current state of knowledge, since the identification of the advantages and contributions of introducing and implementing the BSC may facilitate its adoption and development in organizations that aim to implement this tool. In addition, similar to that pointed out by Agarwal (2012), a theoretical basis for subsequent research is provided, proving the scope of the research on the topic studied.

The work presents a set of limitations, especially related to the fact that it is based solely on the bibliographic review and that it is focused exclusively on the advantages, contributions and critical success factors of the BSC. However, other studies highlighted the fact that despite the vast amount of advantages associated with the implementation of the BSC, its use has not been generalized in many organizations, mainly motivated by a set of barriers that may prevent or limit its chances of success. On the other hand, similar to the work by Lueg (2015), it is worth pointing out as limitations, the probability of some relevant articles having been left out of the consulted database, the fact that we focus specifically on the BSC, omitting other practices of similar management, and the fact that the studies reviewed are based on different ontologies and etymologies, which limit the comparability of their findings.

As suggestions for future research, we understand that it would be important to carry out empirical studies, in particular, of case studies, in organizations of different sectors of activity and of different nature (public and private), that have adopted the BSC, so as to identify the main advantages and also the obstacles and difficulties faced by its implementation.

\section{Declaration of Conflicting Interests}

The authors declared no potential conflicts of interest with respect to the research, authorship, and/or publication of this article.

\section{Funding}

The authors received no financial support for the research, authorship, and/or publication of this article.

\section{References}

Agarwal, S. (2012). Writing a Review Article: for the Beginners in Research. International Journal of Science and Research, 3(10), 813-815.

Albright, T., \& Burgess, C. (2013). Best Practices of High-Performing Employees: Rewards and Performance in a Balanced Scorecard Environment. Journal of Corporate Accounting \& Finance, 24(6), 59-65. https://doi.org/10.1002/jcaf.21893

Alvarez, J. (1998). Integración del Balanced Scorecard y la EFQM en la Teoría de los Stakeholders. Boletín AECA,46, 36-41.

Atkinson, A., \& Epstein, M. (2000). Measure for Measure: Realizing the Power of the Balanced Scorecard. CMA Management, 74(7), 22-28.

Ballvé, A. (2006). Creando Conocimiento en las Organizaciones con el Cuadro de Mando Integral y el Tablero de Control. In ACCID, Nuevas Tendencias en Control y Contabilidad de Gestión (pp 13-38). Barcelona: Ediciones Deusto.

Bedford, D., Brown, D., Malmi, T., \& Sivabalan, P. (2008). Balanced Scorecard Design and Performance Impacts: Some Australian Evidence. Journal of Applied Management Accounting Research, 6(2), 17-36.

Bhagwat, R., \& Sharma, M. (2007). Performance Measurement of Supply Chain Management: A Balanced Scorecard Approach. Computers \& Industrial Engineering, 53(1), 43-62.

https://doi.org/10.1016/j.cie.2007.04.001 
Bisbe, J., \&, Barrubés, J. (2012). The Balanced Scorecard as a Management Tool for Assessing and Monitoring Strategy Implementation in Health Care Organizations. Revista Española de Cardiología, 65(10), 919-927. https://doi.org/10.1016/j.recesp.2012.05.014

Braam, G., \& Nijssen, E. (2011). Exploring Antecedents of Experimentation and Implementation of the Balanced Scorecard. Journal of Management and Organization, 17(6), 714-728. https://doi.org/10.1017/S1833367200001139

Brewer, P. (2002). Putting Strategy into the Balanced Scorecard. Strategic Finance, 83(7), 44-52.

Brewer, P. (2003). Incorporar la Estrategia al Cuadro de Mando Integral. Harvard Deusto, Finanzas \& Contabilidad, $55,72-80$.

Butler, A., Letza, S., \& Nealy, B. (1997). Linking the Balanced Scorecard to Strategy. Long Range Planning, 30(2), 242-253. https://doi.org/10.1016/S0024-6301(96)00116-1

Carvalho, C., \& Azevedo, G. (2001). Balanced Scorecard - Sistema de Informação vs Sistema de Gestão. Revista Estudos do I.S.C.A.A., 6/7, 55-78.

Chavan, M. (2009). The Balanced Scorecard: A New Challenge. The Journal of Management Development, 28(5), 393406. https://doi.org/10.1108/02621710910955930

Chow, C., Haddad, K., \& Williamson, J. (1997). Applying the Balanced Scorecard to Small Companies. Management Accounting, 79(2), 21-27.

De Geuser, F., Mooraj, S., \& Oyon, D. (2009). Does the Balanced Scorecard Add Value? Empirical Evidence on its Effect on Performance. European Accounting Review, 18(1), 93-122.

https://doi.org/10.1080/09638180802481698

Denton, G., \& White, B. (2000). Implementing a Balanced Scorecard Approach to Managing Hotel Operations. Cornell Hotel and Restaurant Administration Quarterly, 41(1), 94-107. https://doi.org/10.1177/001088040004100127

Dhingra, A. (2006). Executing Strategy in the Financial Services Industry: The Key to Competitive Advantage. Cost Management, 20(4), 31-39.

Epstein, M., \& Manzoni, J. (1997). The Balanced Scorecard and Tableau de Bord: Translating Strategy into Action. Management Accounting, 79(2), 28-36.

Epstein, M., \& Manzoni, J. (1998). Implementing Corporate Strategy: From Tableaux de Board to Balanced Scorecards. European Management Journal, 16(2), 190-204. https://doi.org/10.1016/S0263-2373(97)00087-X

Fernández, A. (2002). Claves para la Implantación del Cuadro de Mando Integral. Harvard Deusto, Finanzas \& Contabilidad, 46, 10-17.

Frigo, M. \& Krumwiede, K. (1999a). The Balanced Scorecards: A Winning Performance Measurement System. Strategic Finance, 81(7), 50-54.

Frigo, M., \& Krumwiede, K. (1999b). Balanced Scorecards: A Rising Trend in Strategic Performance Measurement. Journal of Strategic Performance Measurement, 3(1), 42-45.

Gil, A. (2010). Como Elaborar Projetos de Pesquisa. São Paulo: Atlas.

Headley, J. (1998). Aspectos Prácticos de la Implantación del Cuadro de Mando Integral. Harvard Deusto, Finanzas e Contabilidad, 22, 35-41.

Hendricks, K., Hora, M., Menor, L., \& Wiedman, C. (2012). Adoption of the Balanced Scorecard: A Contingency Variables Analysis. Canadian Journal of Administrative Sciences, 29(2), 124-138. https://doi.org/10.1002/cjas.229

Hendricks, K., Menor, L., \& Wiedman, C. (2004). The Balanced Scorecard: To Adopt or not Adopt?. Ivey Business Journal, 69(2), 1-9.

Hepworth, P. (1998). Weighing it Up: A Literature Review for the Balanced Scorecard. Journal of Management Development, 17(8), 559-563. https://doi.org/10.1108/02621719810228416 
Hoque, Z. (2014). 20 Years of Studies on the Balanced Scorecard: Trends, Accomplishments, Gaps and Opportunities for Future Research. The British Accounting Review, 46(1), 33-59.

https://doi.org/10.1016/j.bar.2013.10.003

Hoque, Z., \& James, W. (2000). Linking Balanced Scorecard Measures to Size and Market Factors: Impact on Organizational Performance. Journal of Management Accounting Research, 12(1), 1-17.

https://doi.org/10.2308/jmar.2000.12.1.1

Horváth \& Partners (2003). Dominar el Cuadro de Mando Integral: Manual Práctico Basado en Más de 100 Experiencias. Barcelona: Ediciones Gestión 2000.

Kanji, G., \& Sá, P. (2001). Kanji’s Business Scorecard. Total Quality Management, 12(7/8), 898-905. https://doi.org/10.1080/09544120100000013

Kaplan, R., \& Norton, D. (1992). The Balanced Scorecard - Measures that Drive Performance. Harvard Business Review, 70(1), 71-79.

Kaplan, R., \& Norton, D. (1993). Putting the Balanced Scorecard to Work. Harvard Business Review, 71(5), 134147.

Kaplan, R., \& Norton, D. (1996a). Translating Strategy into Action - The Balanced Scorecard. Massachusetts: Harvard Business School Press.

Kaplan, R., \& Norton, D. (1996b). Using the Balanced Scorecard as a Strategic Management System. Harvard Business Review, 74(1), 75-85.

Kaplan, R., \& Norton, D. (2000). El Cuadro de Mando Integral (The Balanced Scorecard). Barcelona: Ediciones Gestión 2000.

Kaplan, R., \& Norton, D. (2001). The Strategy Focused Organization: How Balanced Scorecard Companies Thrive in the New Business Environment. Massachusetts: Harvard Business School Press.

Kaplan, R., \& Norton, D. (2004). Mapas Estratégicos: Convirtiendo los Activos Intangibles en Resultados Tangibles. Barcelona: Ediciones Gestión 2000.

Kaplan, R., \& Norton, D. (2007a). Using the Balanced Scorecard as a Strategic Management System. Harvard Business Review, 85(7/8), 150-161.

Kaplan, R., \& Norton, D. (2007b). Alignment: Cómo Alinear la Organización a la Estrategia a través del Balanced Scorecard. Barcelona: Ediciones Gestión2000.

Kollberg, B., \& Elg, M. (2011). The Practice of the Balanced Scorecard in Health Care Services. International Journal of Productivity and Performance, 60(5), 427-445. https://doi.org/10.1108/17410401111140374

Lawson, R., Stratton, W., \& Hatch, T. (2006). Los Beneficios de un Sistema de Cuadro de Mando. Harvard Deusto, Finanzas \& Contabilidad, 73, 58-70.

Lueg, R. (2015). Success Factors in Balanced Scorecard Implementations - A Literature Review. Management Revue, 26(4), 306-327. https://doi.org/10.5771/0935-9915-2015-4-306

Lueg, R., \& Julner, P. (2014). How are Strategy Maps Linked to Strategic and Organizational Change? A Review of the Empirical Literature on the Balanced Scorecard. Corporate Ownership \& Control, 11(4), 439-446.

Lueg, R., \& Silva, A. (2013). When One Size Does Not Fit All: A Literature Review on the Modifications of the Balanced Scorecard. Problems and Perspectives in Management, 11(3), 86-94.

Madsen, D., \& Stenheim, T. (2015). The Balanced Scorecard: A Review of Five Research Areas. American Journal of Management, 15(2), 24-41.

Malina, M., \& Selto, F. (2001). Communicating and Controlling Strategy: An Empirical Study of the Effectiveness of the Balanced Scorecard. Journal of Management Accounting Research, 13, 47-90.

https://doi.org/10.2308/jmar.2001.13.1.47 
Michalska, J. (2005). The Usage of the Balanced Scorecard for the Estimation of the Enterprise's Effectiveness. Journal of Materials Processing Technology, 162/163, 751-758. https://doi.org/10.1016/j.jmatprotec.2005.02.227

Modell, S. (2012). The Politics of the Balanced Scorecard. Journal of Accounting \& Organizational Change, 8(4) 475489. https://doi.org/10.1108/18325911211273482

Mooraj, S., Oyon, D., \& Hostettler, D. (1999). The Balanced Scorecard: A Necessary Good or an Unnecessary Evil?. European Management Journal, 17(5), 481-491. https://doi.org/10.1016/S0263-2373(99)00034-1

Morisawa, T., \& Kurosaki, H. (2003). Using the Balanced Scorecard in Reforming Corporate Management Systems. NRI Papers, 71, 1-15.

Muñiz, L. (2004). La Esencia del Cuadro de Mando. Harvard Deusto, Finanzas \& Contabilidad, 62, 4-14.

Muñiz, L., \& Monfort, E. (2005). Aplicación Práctica del Cuadro de Mando Integral: Casos Prácticos, Ejercicios e Cuestionarios de Evaluación. Barcelona: Ediciones Gestión 2000.

Niven, P. (2003). El Cuadro de Mando Integral Paso a Paso. Barcelona: Ediciones Gestión 2000.

Oliva, F., \& Borba, V. (2004). Balanced Scorecard: Ferramenta Gerencial para Organizações Hospitalares. São Paulo: Iátria.

Olve, N., Roy, J., \& Wetter, M. (2002). Implantando y Gestionando el Cuadro de Mando Integral (Performance Drivers). Barcelona: Ediciones Gestión 2000.

Oteo, L., Pérez, G., \& Silva, D. (2002). Cuadro de Mandos Integral a Nivel Hospitalario Basado en Indicadores del Modelo EFQM de Excelencia. Gestión Hospitalaria, 13(1), 9-25.

Otley, D. (1999). Performance Management: A Framework for Management Control Systems Research. Management Accounting Research, 10(4), 363-382. https://doi.org/10.1006/mare.1999.0115

Ottoboni, C. (2002). Uma Proposta de Abordagem Metodológica para Implantação do BSC em Pequenas Empresas. Dissertação (Mestrado em Engenharia de Produção). Universidade Federal de Itajubá, Brasil.

Öztürk, E., \& Coskun, A. (2014). A Strategic Approach to Performance Management in Banks: The Balanced Scorecard. Accounting and Finance Research, 3(3), 151-158. https://doi.org/10.5430/afr.v3n3p151

Pereira, G. (2005). Balanced Scorecard em Hospitais. Dissertação (Mestrado em Ciências Contábeis), Universidade Federal do Rio de Janeiro, Brasil.

Pinto, F. (2007). Balanced Scorecard - Alinhar Mudança, Estratégia e Performance nos Serviços Públicos. Lisboa: Edições Sílabo.

Quesado, P. (2005). O Contributo do Balanced Scorecard para a Gestão Estratégica de Custos: Uma Análise Empirica às Grandes Empresas Portuguesas. Dissertação (Mestrado em Contabilidade), Universidade do Minho, Braga, Portugal.

Quesado, P., Guzmán, B., \& Rodrigues, L. (2012a). El Cuadro de Mando Integral en Organizaciones Privadas Portuguesas: Un Análisis Descriptivo. Revista Sociedade, Contabilidade e Gestão, 7(1), 81-106.

Quesado, P.; Guzmán, B. \& Rodrigues, L. (2012b). El Cuadro de Mando Integral en Organizaciones Públicas Portuguesas: Un Análisis Descriptivo. Revista Iberoamericana de Contabilidad de Gestión, 9(19), 1-20.

Rickards, R. (2003). Setting Benchmarks and Evaluating Balanced Scorecards with Data Envelopment Analysis. Benchmarking: An International Journal, 10(3), 226-245. https://doi.org/10.1108/14635770310477762

Ritter, M. (2003). The Use of Balanced Scorecard in the Strategic Management of Corporate Communication. Corporate Communications: An International Journal, 8(1), 44-59. https://doi.org/10.1108/13563280310458911

Rodrigues, A., \& Francisco, R. (2010). Importância Atribuída aos Indicadores da Perspectiva de Aprendizagem e Crescimento do Balanced Scorecard nos Hotéis Portugueses de 4 e 5 Estrelas. In XIV Encuentro AECA, 2324 setembro, Coimbra. 
Sampaio, R., \& Mancini, M. (2007). Estudos de Revisão Sistemática: Um Guia para Síntese Criteriosa da Evidência Científica. Revista Brasileira de Fisioterapia, 11(1), 83-89. https://doi.org/10.1590/S141335552007000100013

Santos, M., \& Fidalgo, E. (2003). Del Cuadro de Mando al Cuadro de Mando Integral: Las "Perspectivas" en la Gestión Sanitaria. In VIII Jornada de Trabajo sobre Contabilidad de Costes y de Gestión, Universidad de Cantabria, 239252.

Santos, M., \& Fidalgo, E. (2004). Un Análisis de la Flexibilidad del Cuadro de Mando Integral (CMI) en su Adaptación a la Naturaleza de las Organizaciones. Revista Iberoamericana de Contabilidad de Gestión, 2(4), 85-116.

Santos, M., \& Fidalgo, E. (2005). El Balanced Scorecard o Cuadro de Mando Integral y el Cuadro de Mando Tradicional: Principales Diferencias. Técnica Contable, 673, 13-17.

Short, J. (2009). The Art of Writing a Review Article. Journal of Management, 35(6), 1312-1317. https://doi.org/10.1177/0149206309337489

Speckbacher, G., Bischof, J., \& Pfeiffer, T. (2003). A Descriptive Analysis on the Implementation of Balanced Scorecards in German-Speaking Countries. Management Accounting Research, 14(4), 361-387. https://doi.org/10.1016/j.mar.2003.10.001

Sundin, H., Granlund, M., \& Brown, D. (2010). Balancing Multiple Competing Objectives with a Balanced Scorecard. European Accounting Review, 19(2), 203-246. https://doi.org/10.1080/09638180903118736

Tan, C., \& Smyrnios, K. (2011). How do Australian Fast-Growth Small-to-Medium Enterprises Measure Performance?. Journal of Enterprising Culture, 19(1), 41-60. https://doi.org/10.1142/S0218495811000672

Tapinos, E., Dyson, R., \& Meadows, M. (2011). Does the Balanced Scorecard Make a Difference to the Strategy Development Process?. The Journal of the Operational Research Society, 62(5), 888-899.

https://doi.org/10.1057/jors.2010.99

Tayler, W. (2010). The Balanced Scorecard as a Strategy-Evaluation Tool: The Effects of Implementation Involvement and a Causal-Chain Focus. The Accounting Review, 85(3), 1095-1117.

https://doi.org/10.2308/accr.2010.85.3.1095

Tominac, S. (2014). Possibilities of Balanced Scorecard Application in Commercial Banks. International Journal of Scientific Research, 3(10), 119-121.

Walker, K. (1996). Corporate Performance Reporting Revisited - The Balanced Scorecard and Dynamic Management Reporting. Industrial Management \& Data System, 96(3), 24-30.

https://doi.org/10.1108/02635579610114929

Xavier, L. (2012). O Controlo de Gestão nas Instituições Financeiras e a Aplicabilidade do BalancedScorecard numa Instituição Financeira a Nivel Regional. Dissertação (Mestrado em Contabilidade e Gestão das Instituições Financeiras), Instituto Politécnico de Lisboa, Lisboa, Portugal.

Zizlavsky, O. (2014). The Balanced Scorecard: Innovative Performance Measurement and Management Control System. Journal of Technology Management \& Innovation, 9(3), 210-222.

https://doi.org/10.4067/S0718-27242014000300016

Intangible Capital, 2018 (www.intangiblecapital.org)

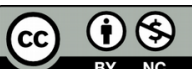

Article's contents are provided on an Attribution-Non Commercial 4.0 Creative commons International License. Readers are allowed to copy, distribute and communicate article's contents, provided the author's and Intangible Capital's names are included. It must not be used for commercial purposes. To see the complete license contents, please visit https://creativecommons.org/licenses/by-nc/4.0/. 